\title{
ورقه عمل حول \\ حمايه البيانات الشخصية في المنظوهة القانونية العمانية
}

\author{
بجاث مفرد الى مؤَثر \\ الجوانب القانونيتّوالاقتصاديت للذهاء الاصطناعي \\ وتكنولوجيا المعلومات \\ rrr \\ كليتا الحقوق- جامعتمالمنصورة مائوة
}

shel

أ.د/ راشد بن حمد البلوشي

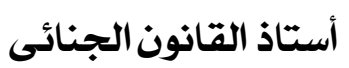

وعميد كليتا الحقوق سابقا

جامعتّ السلطان قابوس الحتوق 
عدد خاص بالمؤتمر الدولى السنوى العشرون أ.د راشد بن حمد البلوشى

\section{ورقة العهل}

سوف تتناول ورقه العمل المواضيع التالية:

اولا: تطور التشريعات المتعلقة بحماية البيانات الثخصية في السلطنة

ثانيا: الحماية الجنائية للبيانات الثخصية في القوانين العُمانية

ثالثاً : الخاتمة و التوصيات

اولا: تطور التشريعات المتعلقة بحماية البيانات الثخصية في السلطنة

ان التشريعيات المتعلقة بوضع تدابير حماية الخصوصية المعلوماتية في مختلف دول العالم اتجهت الى احد ثلاثة اتجاهات:

ا ـ ان تقوم بوضع فوانين عامه تحكم عمليات جمع وادارة ومعالجة البيانات الثخصية في

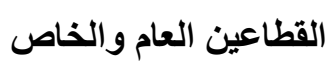

Y ـ القوانين القطاعية المخصصة SECTORAL LAWS

rـ النوع الثالث من التثريعات المنظمـة للخصوصية وحمايـة البيانـات هو التنظيم الذاتي

$$
\text { SELF - REGULATION }
$$

وفيما يتعلق بسلطنة عمان فإنها تبنت النوع الاول من التشريعات حيث سنت قانون شامل يعنى بحماية الخصوصية و البيانات الإكترونية و هو قانون المعاملات الإكترونية رقم 9 / . . . r و هي بذلك وضعت القواعد العامة الثاملة المنظمة لهذا الموضوع. 
عدد خاص بالمؤتمر الدولى السنوى العشرون أ.د راشد بن حمد البلوشى

r - معالجة موضوع حمايـه البيانـات الثخصية في قانون المعاملات الإلكترونية رقم $r \cdot 1 / 79$

أ- المقصود بالخصوصية المعلوماتية في قانون المعاملات الاكترونية:

ان البيانات التي تكون محلاً للحماية وفق قانون المعاملات الإكترونية يجب ان يكون

قد تم الحصول عليها بطريق مشروع وقانوني وأن تستخدم للغرض الاصلي المعلن والمحدد كما أنها يجب أن تتصل بالغرض المقصود من الجمع ولا تتجاوزه ومحصورة بذلك وأن تكون صحيحة وتخضع لعمليات التحديث والتصحيح و يتوفر حق الوصول اليها و تحفظ سرية وتحمى سريتها وأخيرا يجب أن تدمر بعد استنفاذ الغرض من جمعها.

وكاستثناء من القاعدة العامة فقل أجاز القانون في المادة بـ أحصول على البيانـات الثخصية أو الإفصاح عنها أو توفيرها أو معالجتها وبدون الحصول على الموافقة الصريحة لذوي الشأن وذلك في حالات محدة على سبيل الحصر وهي : أ.إذا كانت ضرورية لغرض منع أو كثف جريمة بناء على طلب رسمي من جهات التحقيق. ب.إذا كانت مطلوبة أو مصرحاً بها بموجب أي قانون أو كان ذلك بقرار من المحكمة. ج.إذا كانت البيانات ضرورية لتقدير أو تحصيل أية ضريبة أو رسوم . د.إذا كانت المعالجة ضرورية لحماية مصلحة حيوية للشخص المجموعة عنه البيانات. ب- ضمان سرية البيانات الثخصية من قبل مقدم خدمات التصديق : نصت المساده (ع ؛ ) مـن القـانون على انـه "" مـع مراعـاة الفقرة الثانيـة مـن المـادة السابقة (بّ ؛)، يتعين على مقدم خدمات التصديق اتباع الاجراءات المناسبة لضمان سرية البيانات الثخصية التي في عهدته في سياق القيام بواجباته ولا يجوز له افثناء او تحويل او 
عدد خاص بالمؤتمر الدولى السنوى العشرون أ.د راشد بن حمد البلوشى

اعلان او نشر تلك البيانات لأي غرض مهما كان إلا بموافقة مسبقة من الثخص الذي جمت

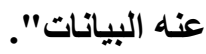

بـ - الحقوق الخاصة بالأفراد

أـ حق النفاذ الى المعطيات و تعديلها المادة (7 ؛ )

بـ الحق في الاعتراض على معالجة البيانات الثخصية المادة ( \؛)

ثانيا:الحماية الجنائية للبيانات الثخصية في القوانين العُمانية صدر قانون مكافحة جرائم

تقنية المعلومات رقم ب / / 1 1 ــ الذي جاء ليواكب التطور المتسارع في الحياة الذي

أدى إلى تطور في مستوى وقوع جريمة تقتية المعلومات حيث جرم هذا القانون العديد

من الأفعـال التـي تشكل تعديا على مستخدمي الشبكة المعلوماتيـة ووســائل تقنيـة

المعلومـات، مثل جريمـة التعدي على سـلامة وسـرية البياتـات والنظم المعلوماتيـة

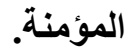

ثالثًا : الخاتمة و التوصيات

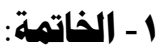

ممـا تقدم يمكن القول ان قـانون المعـاملات الإكترونيـة بوصفه أول تشريع عمـاني

متكامل لتنظيم المعاملات التي تتم في العالم الرقمي قد مكن من استخدام الوسـائل الإكترونية في تحرير وتبادل وحفظ المستندات، كما انه حفظ حقوق المتعاملين وضمن مصداقية وقانونية المعاملات الإكترونية و حماية البيانات في آن واحد.

بالإضافة الى ذلك، فإن قانون مكافحة الجرائم المعلوماتيـة قد وفر الحمايـة الجنائية للبيانات الثخصية و يعتبر هذا الموضوع هو الاساس لتعزيز ثقة الجمهور في حمايه البيانات 
عدد خاص بالمؤتمر الدولى السنوى العشرون أ.د/ راشد بن حمد البلوشى

الثخصية في المنظومة القانونية العمانية، و هو بذلك كله يضمن توافر الثقة والرقابة اللازمة لصحة وسلامة المعاملات الإكترونية و حماية البيانات الثخصية

r- من هيث التوصيات:

1ـ لعل المحاولات التي تجريها الحكومة حاليا في سلطنة عمان حول اصدار قانون خاص بحمايسة البياتـات الثخـصية سـوف تزيـــ مـن تعزيـز ثقــة الجمهـور فـي التعـاملات الالكترونية بشكل عام والتعامل مع وسائل التواصل الاجتماعي بشكل خاص.

r - نرى ان يمكن القانون ويتيح للمستخدم التحكم في ضبط الاعدادات الخاصـة بالتواصل الاجتمـاعي وإيجـاد اليهل تمكنهـه من التحكم في تحديد نطاق الخصوصية في حسابه الثخصي و يختار من يسمح له بان تكون بياناته الثخصية في متناوله. ץـ ضـرورة الاهتمـام بتطوير وسـائل الاثبـات المتعلقة بانتهـاك الخصوصية على مواقع التواصل الاجتمـاع والتعدي على البيانـات الثخصية للأفراد والمؤسسات، وذلك من خـلال وضـع قواعد قانونيـة تـساعد على زيــادة المـصداقية التـي تثتمتع بهـا الأدلـة المتحصلة و التي يمكن استخذامها في الاثبات على الانتهاكات للخصوصية و البيانات الثخصية. ـ ـ أخيرا لابد من وجود تنظيم قانوني اكثر وضوحا سواء من حيث سن القواعد الفنيـة او القواعد القانونية الخاصة بمعالجة البيانات الثخصية خصوصا على مواقع التواصل الاجتماعي. 